\title{
Identity, Motivation and English Learning in a Japanese Context
}

\author{
Nooshin Goharimehr ${ }^{1, *}$ \\ ${ }^{1}$ Department of Critical Studies in Education for Transformation, Graduate School of Human Sciences, Osaka \\ University, Japan \\ *Correspondence: Department of Critical Studies in Education for Transformation, Graduate School of Human \\ Sciences, Osaka University, Japan. E-mail: ngohari2014@gmail.com
}

Received: October 2, 2017

Accepted: October 28, 2017 Online Published: December 17, 2017

doi:10.5430/wjel.v7n4p18

URL: https://doi.org/10.5430/wjel.v7n4p18

\begin{abstract}
Founded upon motivation, identity and self theories, this qualitative case study explored the motivational self system and identities of Japanese EFL learners and their influence on motivation and English language learning. Data was collected through online surveys among 22 graduate and undergraduate university students. The survey results indicated high motivation, international orientation and positive attitudes toward English language learning. The thematic analysis of students' detailed responses to the open-ended questions showed a stronger instrumental motivation and lack of desire to join and identify with the English communities and culture. International orientation appeared to be a better measure of motivation as opposed to integrative motivation. Moreover, the learners had inhibitory factors operating against English learning motivation and speaking practices such as anxiety and low linguistic self-confidence. Resistance to new cultural identities or identity conflicts resulted from different cultural contexts show to be an influencing factor in L2 learning. In sum, combining Gardner's views on motivation, Norton's conceptions of identity and Dörnyei's L2 Motivational Self System together with qualitative approaches might render a deeper understanding of motivational barriers of Japanese EFL learners.
\end{abstract}

Keywords: identity; motivation; motivational self system; English language learning

\section{Introduction}

In the context of English language learning, there is a need for more academic research on motivation and identity to investigate the reasons why Japanese students are particularly afflicted by a reluctance and lack of confidence to speak in a second language and achieve lower scores on English tests in international levels (ETS, 2010). Recently, researchers are shifting their focus from an integrativeness approach to the internal self-concept of the L2 learners in motivation research. However, most of the previous studies on the L2 motivational self-system have focused on quantitative methods. The concepts of identity and motivation are deeply rooted in individual's psychology, hence, in addition to quantitative methods, qualitative research will be useful to understand the dynamic system of motivation by adding "thick description" drawn from individuals.

Moreover, most studies have been conducted in ESL contexts of immigrant communities in the USA, Canada and Australia and there is a lack of research in EFL contexts such as Japan with regard to cultural and contextual impacts (McKay and Wong, 1996; Pavlenko and Lantolf, 2001). Norton (1995) points out a need for developing a comprehensive theory of social identity that integrates the language learner and the language-learning context. Using Gardner's Motivation and attitude model (2011), Dörnyei's L2 Motivational Self System (Dörnyei \& Ushioda, 2009) and Norton's seminal work on Identity(2013), this study seeks to understand the motivation of language learners and its relationship with self (identity), and the learning context. It tries to address the following major questions:

1. What are the motivational orientations of Japanese EFL learners?

2. What is the role of self and identity in their English learning motivation?

\section{Literature Review}

Since Norton's work on identity in the 1990s, researchers (Dornyei \& Ushioda, 2009, Gao \& Lamb, 2011) have 
focused on identity-oriented (rather than achievement-oriented) theories of motivation in mainstream educational psychology in language learning. Norton (2013) defines identity as "how a person understands his or her relationship to the world, how that relationship is structured across time and space, and how the person understands possibilities for the future. It's through language that we represent our identities and construct new ones. Identities form in relation to a context while there are relationships between our different selves (Gee and Crawford, 1998). There, is a connection between language, identify and the cultural context. Hence, attaining L2 competency inevitably involves the issue of social identity and the development of an L2 self. Meanwhile, L2 identity and motivation provide powerful means to explore the learners' sociocultural context (Miller, 2009).

Luke (1996) argues that learners have multiple social identities that help them take on different positions in daily interactive behaviors and that those positions "offer possibilities for difference, for multiple and hybrid subjectivities that human subjects make and remake..." (p. 14). As Richards (2006, p.72) notes, engaging the learners' identities in the classroom will necessarily involve an investment of self, with all the emotional, relational and moral considerations this entails. Through this experience of expressing themselves in the target language, they are thus enabled to engage directly with their future possible selves as proficient users of this language but within the scope and security of their current communicative abilities, interests and social contexts (Ushioda, 2010). Accordingly, Norton (1995) points out the need for teachers to accommodate English learner dynamic identities and listen to how learners negotiate different identities as they employ diverse cultural and linguistic resources to construct knowledge in classrooms.

To understand the concept of identity, we need to consider the connection between identity goals which relate the self to the social context and second or foreign language learning motivation (van Lier, 2007). Gardner (1985) defines motivation as a combination of desire and effort to learn a language. The integrative motivation as proposed by Gardner and Lambert (1972) refers to the degree a learner is open to the target culture and identifies himself with the target community. The extent to which learners position themselves in relation with the L1 and L2 community and culture determines their integrativeness and similarly the integrativeness or the intensity of the learner's desire to be closer to the target community members, determines the degree of L2 acquisition and motivation to learn the target language (Gardner \& Lambert, 1959). Gardner (2011) created the Attitude and Motivation Test Battery (AMTB) to quantitatively measure the four main factors and their sub-units which consist of integrativeness, attitude toward learning situation, motivation and language anxiety.

While L2 identity involves the adoption of a new culture and identifying with the sociocultural aspects of the target language, Gardner was criticized for putting too much emphasis on integrativeness. For some EFL learners, the target community with which to identify is quite obscure and there is no clearly defined target language community into which they are motivated to 'integrate' in a world of cyberspace and online communication networks. Therefore, integrative motivation in its strong form as identification with and a desire to integrate into the target language community loses its explanatory power, as English is fast becoming a basic educational skill in primary curricula (Graddol, 2006).

The integrative motivation or the desire to mingle with the native speakers is similar with the notion of imagined community by Norton (2000). Imagined community is a community of imagination, a desired community that is not immediately accessible and offers a range of possible future identities. Nevertheless, this is not necessarily a native community of the target language, and can be an international community that uses English as a lingua franca. Hence, the concept of Imagined community provides a better understanding of the learners' motivations. Norton (2001, p. 170) argues that some learners quit community ESL programs due to a "disjuncture between the learner's imagined community and the teacher's curriculum goals" while some learners choose to continue and exercise non-participation in order to resist dominant narratives of being positioned into certain identity roles (Lantolf \& Pavlenko, 2001).

In the EFL context, the space to use English actively is somewhat limited, so the classroom becomes an important place to "validate learners as interlocutors in the new speech community" (Boxer \& Cortes-Conde, 2000, p. 203). However, some students might be discouraged by the mismatches between what they imagine to be an English class as a community of practice and their desire to be able to try to develop desired identities and a curriculum that is inflexible, teacher centered or designed to only achieve academic purposes.

Another theory which utilizes motivation and identity is Dörnyei's (2005) L2 Motivational Self System suggesting that a learner is motivated when challenged to achieve a desirable self-image using the target language, the "ideal L2 self" (Dörnyei \& Ushioda, 2009). The model consists of the three dimensions. The deal L2 Self promotes motivation by inspiring the present self to strive to become the ideal self, which is the kind of L2 user one aspires to be in the future. The ought-to L2 self includes the attributions that one believes one ought to possess as a result of perceived duties, 
obligations, or responsibilities (Dörnyei, 2005). The L2 learning experience concerns the situational and environmental aspects of the language learning process as well as one's subjective learning experience and attitudes toward second language learning.

While Dörnyei's model provide a strong tool to scrutinize L2 motivation, Norton (2000) proposes another important concept which is "investment" to replace the role of motivation by claiming that the amount that learners invest in language learning may affect learner identity. Investment recognizes that the language learner has a complex social identity, which changes across time, and space and that learners often have different investments in the language practices of their classrooms and communities (p. 17).

Although sociocultural and identity theories like Norton's construct of investment and psychological theories of motivation such as Dörnyei's L2 motivational self-system are traditionally used separately, bringing the two together may offer a more comprehensive understanding of learners' variable desire to engage in social interaction inside and outside the L2 classroom. Regarding Norton's ideas, Wang (2010) discussed the role of learner identity in study-abroad context, and she considered that Identity had to do with the degree of belonging to a certain discourse community, that is, membership as perceived by the new member and the existing members. She found that the amount and the quality of interactional encounters with native speakers, along with learners' identity, play a major role in language acquisition in the SA context. Kanno (2003) studied bilingual speaker identities in the outer circle countries and provided interesting examples of how identities are constructed in relation to languages and the society. In fact, many of the researches on learner identity have focused on the influence of different environments on learning.

In Japan several studies focused on motivation of EFL learners. Despite the fact that Japanese students are having positive attitude towards English speaking community and cross-cultural communication, they are assumed to have low motivation and reluctance to speak in a second language (Matsuda, 2000, Hollingworth, 2017). Research shows that integrativeness is not an adequate measure of motivation for Japanese students who have little desire to identify with the target culture or access English speaking communities. Yashima (2000) proposed the concept of international posture as opposed to integrative motivation. Her research shows that there is a negative relationship between intercultural orientation and ethnocentrism which indicates the importance of more research on contextual and cultural factors behind the students' performance. She argues that for most Japanese learners identifying with the target culture is not an important goal.

Hedge (2000) conducted a study that investigated the motivation of 20 Japanese students who were studying English. The findings indicated that the most common reasons for studying English as a second language were for communication with people overseas, finding employment in a high profile career, processing international information, and understanding other cultures. Although these studies shed light on motivational orientations of Japanese students, there is still a need for more qualitative research to understand the reasons behind their motives. Dörnyei and Norton provide useful tools to conduct an analysis of the socio-psychological processes that affect the learners' identity and motivation.

\section{Methodology}

Participants: The participants of this study were 22 Japanese male and female students in graduate and undergraduate levels who had taken English courses in Japanese universities. They were recruited through researcher's observing participation in an Integrated English speaking course as well as English language exchange events.

Instrumentation: A 35-item survey was designed which consisted of three parts:

1. General demographic and background information of students such as gender, age, major and undertaken English courses, 2. Students' motivation and attitude toward English language learning and the target culture and additional open-ended questions on subjects' relevant comments on students' motivation, imagined communities and identities, 3. English learning goals, learning barriers, positive and negative learning experiences, and attitudes toward English language learning.

Procedure: The research design of this study consisted of descriptive statistical analysis, Grounded theory, thematic analysis and psychological discourse analysis. The online survey included two sets of questions, 3-Likert scale items and open-ended questions. The survey was designed based on Gardner's (2011) motivation battery and included positively worded and negatively worded items, which addressed the following variables: Motivation, Attitudes toward English language and people, English Class Anxiety, Integrative Orientation, Instrumental Orientation and 
International Posture. This was integrated into another set of open-ended questions to obtain data on other research questions.

\section{Results and Discussion}

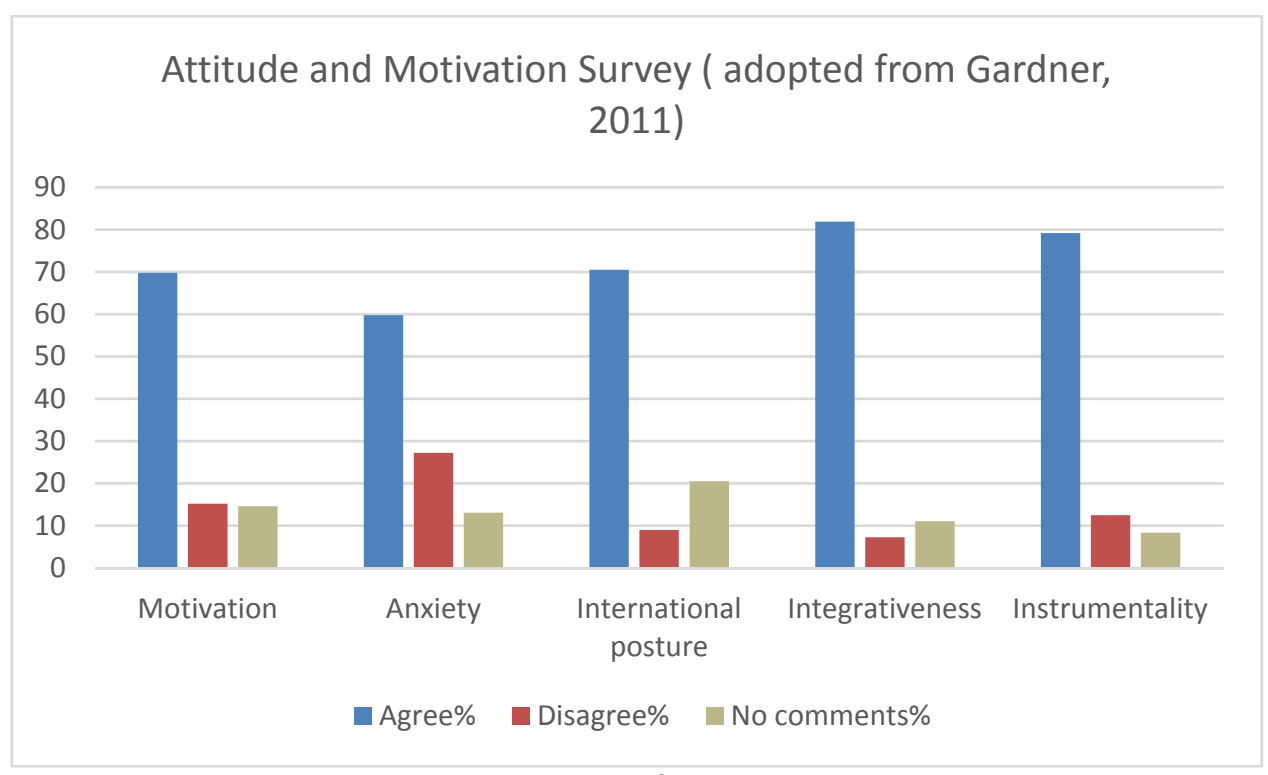

Figure 1. Summary of Survey Responses

\subsection{Motivation}

Table 1. Motivation and Attitudes Toward English Language and People $(\mathrm{N}=22)$

\begin{tabular}{llll}
\hline Motivation and Attitudes Toward English Language and People & Agree & Disagree & $\begin{array}{l}\text { No } \\
\text { comments }\end{array}$ \\
\hline 1. I have more knowledge and more understanding when studying English. & 65.85 & 24.15 & $10 \%$ \\
2. I feel excited when I communicate in English with others. & 72.5 & 17.5 & 10 \\
3. I enjoy doing activities in English. & 71.5 & 18.35 & 10 \\
4. I like the English class so much; I look forward to studying more English in the & 63.35 & 18.35 & 18.3 \\
future. & & & \\
5. I wish I could speak English fluently. & 100 & 0 & 0 \\
6. Knowing English is an important goal in my life. & 54.15 & 32.5 & 13.35 \\
7. I like to practice English the way native speakers do & 62.5 & 13.35 & 24.15 \\
8. Studying English makes me have more confidence in expressing myself. & 66.65 & 28.35 & 5 \\
9. I can share some ideas in English better than Japanese. & 23.35 & 38.35 & 38.35 \\
10. I prefer studying in my mother tongue rather than any other foreign language. & 23.35 & 54.15 & 22.5 \\
11. I cannot apply the knowledge from English subject in my real life. & 4.15 & 72.5 & 23.35 \\
12. Frankly, I study English just to pass the exams. & 4.15 & 81.65 & 14.15 \\
13. English subject has the content that covers many fields of knowledge. & 50 & 10 & 40 \\
14. In my opinion, people who speak more than one language are more & 50 & 30 & 20 \\
knowledgeable. & & & \\
15. I'm interested in English speaking people. & 81.65 & 5 & 13.35 \\
\hline
\end{tabular}


With regard to the questions about attitude toward English language learning, a relatively high average percentage of agreement with positive statements (69.76) indicates that most of the participants hold positive attitude and high motivation in English learning. The analysis summary is presented in the following tables. All students agreed with the statement 6 (I wish I could speak English fluently) which indicates their desire to learn the language however, only 54.15\% admitted that English learning is an important goal in their life. This may be connected to the learner's ambivalent desire to learn the language. Norton (2013) distinguishes between language learner's motivation and investment arguing that investment is related to the socially and historically constructed relationship between the learner identity and learning commitment. Learners invest in a language understanding that they will access to a range of symbolic and material resources, which increases the value of their cultural capital and social power. Hence, although these learners seem to be motivated and have a strong desire in learning, they might not be invested and committed to learning the language as an important life goal. Moreover, $81.65 \%$ agreement with the statement 15 indicates the learners' interest in English speaking people and positive attitude toward the target community.

\subsection{Motivational Orientations and International Posture}

Another goal of the study was understanding the motivational orientations of English learners. The summary of percentages in figure 1 and table 1 show that the learners have both instrumental and integrative motivations and it's high on both levels (instrumental: $75.83 \%$ and integrative: $81.87 \%$ ).

Table 2. Integrative Orientation, Instrumental Orientation $(\mathrm{N}=22)$

\begin{tabular}{|c|c|c|c|}
\hline Integrative Orientation, Instrumental Orientation & Agree & Disagree & No comments \\
\hline $\begin{array}{l}\text { 16. I would like to learn about the people and culture of } \\
\text { English speaking countries. }\end{array}$ & 86.65 & 5 & 9.15 \\
\hline 17. I wish I could have many English-speaking friends. & 80.85 & 10 & 9.15 \\
\hline $\begin{array}{l}\text { 18. I have thoughts that I want to share with people from } \\
\text { other parts of the world. }\end{array}$ & 77.5 & 9.15 & 13.35 \\
\hline $\begin{array}{l}\text { 19. I would like to practice English out of classroom with } \\
\text { people who speak English. }\end{array}$ & 82.5 & 5 & 12.5 \\
\hline $\begin{array}{l}\text { 20. Studying English helps me have good relationships with } \\
\text { friends. }\end{array}$ & 69.15 & 14.15 & 16.65 \\
\hline 21. Studying English makes me able to create new thoughts. & 77.5 & 14.15 & 8.35 \\
\hline $\begin{array}{l}\text { 22. Being good at English will help me study other subjects } \\
\text { well. }\end{array}$ & 90.85 & 9.15 & 0 \\
\hline
\end{tabular}

Looking at the students' responses to the open-ended questions about learning motivations also revealed the presence of both aspects. The desire to make foreign friends and learning about foreign cultures represents integrative motivation although it's not the strongest form which is identification with the target culture and being part of them. Getting access to knowledge and widening the perspectives are related to instrumental aspects of learning. As it can be seen in table 2, most of the students mentioned expansion of horizons as an important goal. For them, English is a means to reach out to the outer world and adopt new identities.

Excerpt 3:

"I'm learning English to make friends with foreigners."

"Because I want to know different and various perspectives. I want to be a person who has a lot of knowledge and understandings about various cultures." 


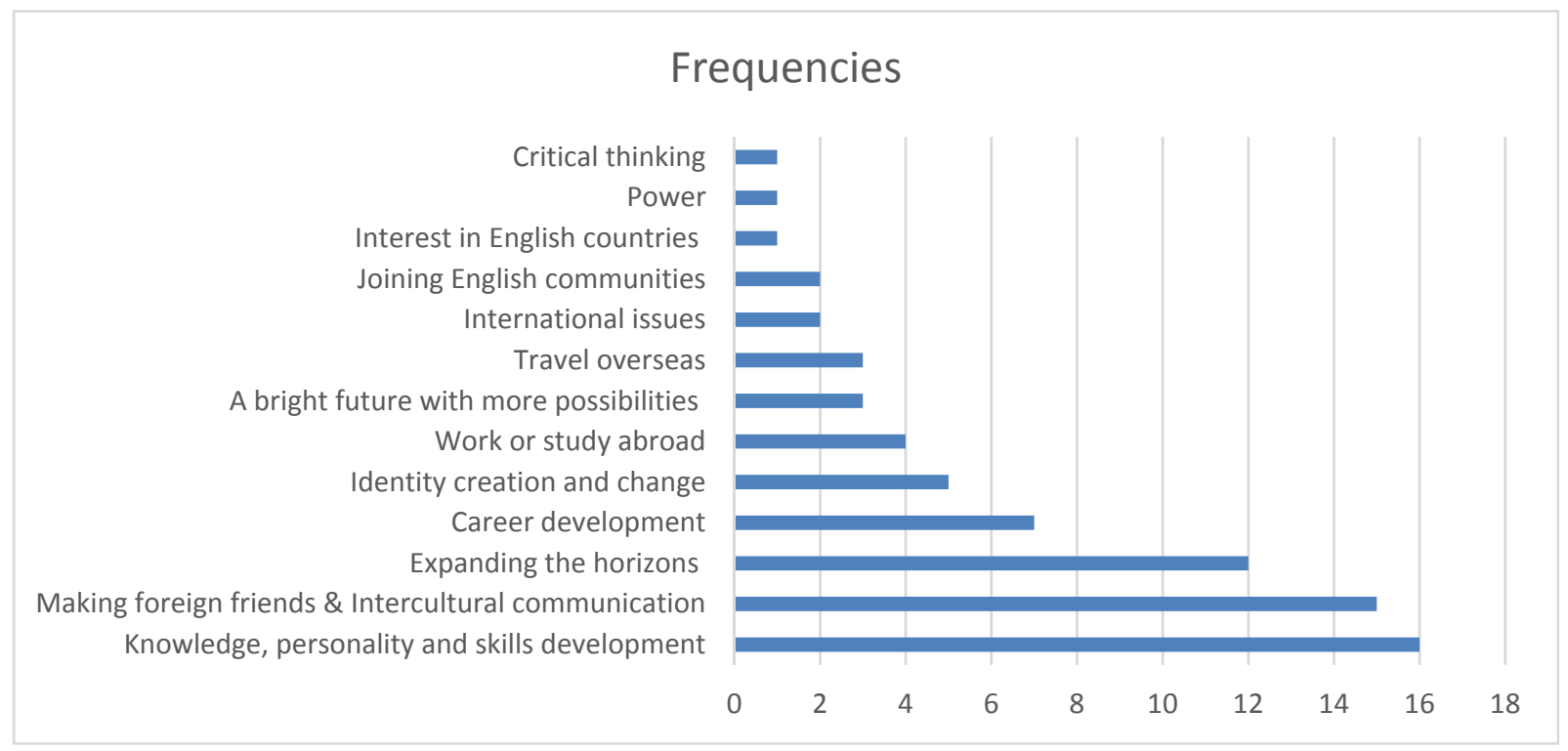

Figure 2. Thematic Analysis of Responses to Open-Ended Items; English Learning Goals

As it is evident from table 2, some themes appeared more frequently in the participants' responses: Knowledge, personality and skills development, making foreign friends, intercultural communication and expanding the horizons. The most frequent theme which is the enhancement of personality, skills and knowledge represent instrumental goals. Making foreign friends and international communication can be best defined with the concept of international posture. Integrativeness in its strong form is represented in the themes of interest in English countries and joining English communities which were mentioned less often.

Table 3. International Posture $(\mathrm{N}=22)$

\begin{tabular}{llcc}
\hline International posture & Agree & Disagree & $\begin{array}{l}\text { No } \\
\text { comments }\end{array}$ \\
\hline $\begin{array}{l}\text { 23. I want to make friends with international students or foreigners } \\
\text { in Japan. }\end{array}$ & 85 & 5 & 10 \\
$\begin{array}{l}\text { 24. I would like to study or travel overseas. } \\
\text { 25. I am interested in an international career. }\end{array}$ & 90.85 & 4.15 & 5 \\
$\begin{array}{l}\text { 26. I often read and watch news about foreign countries } \\
\text { 27. I have ideas about international issues, such as environmental } \\
\text { issues and north-south issues. }\end{array}$ & 73.35 & 5 & 31.65 \\
\hline
\end{tabular}

According to the survey, there is a high a degree of international posture (70.51\%) and intercultural orientation as it was found in previous studies (Yashima, 2000). Learners show a positive attitude and interest in intercultural communications and some degrees of integrativeness which is reflected in their desire to talk to foreigners. Several themes such as interest in international issues, work or study abroad, and international communications appeared more often which indicate the strong international posture as opposed to integrative motivation. Hence, the instrumental motivation is much stronger for most Japanese learners and a strong desire to be identified with English people and culture is not a prior goal. Their motives are mostly related to education, career and personality development and the learners are internationally orientated rather than aiming to be identified with an English community. 


\subsection{Anxiety}

Table 4. English Class Anxiety ( $\mathrm{N}=22)$

\begin{tabular}{llll}
\hline English Class Anxiety & Agree & Disagree & No comments \\
\hline 28. I get anxious and nervous when I speak English with foreigners. & 60.85 & 30 & 9.15 \\
29. I get anxious when I have to answer a question in my English class. & 60.85 & 21.65 & 17.5 \\
30. Speaking English in class makes me feel worried. & 57.5 & 30 & 12.5 \\
\hline
\end{tabular}

In response to the second research question, a short look at figure 1 and table 1 (statements 17, 18\&19) suggests that more than half of the participants $(59.77 \%)$ have a high degree of anxiety. Moreover, the students' comments also indicate high anxiety and low level of linguistic self-confidence regarding their speaking skills in different situations inside and outside of the classroom. These comments shed more light into their anxiety:

Excerpt 1:

“...Until junior high school, I could speak English fluently, because there were English conversation classes in junior high school. But in senior high school, there were not English speaking classes that my speaking skill became poor and poor. When I see someone who can speak English fluently, I feel no confidence and have the worst thought. So now, I'm shy and poor in speaking English that I feel so nervous and no confidence when I (am) speaking English to people."

"When I was high school student, my host mother praises my English so much. Then, I could have confidence."

"When I met with my teacher for the first time since few years who do really good for me and I respect him, He sweat a lot and said "Sorry I am stinky." And I said "Ah, Yes" I said that without understand(ing) "stinky" My teacher's face has been bad mood a little then. I could not understand what happen at that time, But I got to know few days later. I regret this thing so much. If the teacher just does not contact so long to me, I feel that he hates me."

"I usually don't feel comfortable to speak English."

"I feel comfortable speaking English when my English is understood, (with)people whose native language is not English rather than native speakers."

"When I went to the U.S.A.,I met many people who have different ideas, and moreover they speak with confidence. Through talking with them, I want to make my opinion clear and tell it to them."

Through these comments, it is understood that a major factor in the learners' linguistic difficulty is anxiety and lack of linguistic self-confidence. As Dörnyei (2005) said, different social contextual factors affect learning a second language and among those factors, linguistic self-confidence plays the most important role in motivation in learning a second language. These results have appeared in previous studies implying that Japanese learners have high anxiety and a low level of linguistics self-confidence due to cultural reasons. Many learners reported to be uncomfortable in unclear situations and facing with ambiguity. Despite the fact that Japanese students are often reported to be poor in speaking abilities or language learning motivation, the results suggest that the Japanese learners participated in this study are highly motivated in English learning and are interested in English people and possibly their perceived poor speaking proficiency is due to language anxiety facing with foreigners. As Horwitz et al. (1986) clearly noted, "Any performance in the L2 is likely to challenge an individual's self-concept as a competent communicator and lead to reticence, self-consciousness, fear, or even panic" (p. 128). In a self-reflective study on Japanese learners' anxiety, Ohata (2005) found that the characteristics of language anxiety exhibited by the participants seemed to be quite influenced by Japanese cultural norms or expectations acquired through numerous socialization processes in Japan. In some cultural contexts as in Japan, for instance, it is considered undesirable or unacceptable for talented students to stand out from their peers (Tsui, 1995).

Another reason for low speaking practices could be the cultural fact that Japanese have very different ideas about how to express a difference of opinion or freely express thoughts in a conversation, which might cause anxiety in English speaking. English language is straightforward and Japanese is indirect. The differences between the two languages and cultures can be best defined by Hofstede's model of cultural dimensions (Hofstede, 1991). According to this mode, Japanese tend to express their opinions less often and less directly as a sense of collectivism. While in 
most Western cultures, it's considered important to get differences of opinion on the table. Debate is a skill honed at school and throughout life, and can even be considered an enjoyable pastime. People tend to be judged on their ability to make a persuasive argument. Japanese have a low level of ambiguity tolerance which makes them avoid the situations where they might lack information or fail responding well. The cultural and linguistic anxiety is implied well from a participant's comment on his negative experiences in speaking English:

Excerpt 2:

"When I am asked my opinion, I often consider too seriously. I can't find good word for express my opinion and I fall silent. Sometime my conversation partner changes the question to yes-or-no question, and I feel relieved"

He mentions that he takes the argument seriously and feels nervous to express his opinion. So he prefers to resort to Yes/No questions to avoid any ambiguity, anxiety and face-threatening situations. This is due to the fact that Speaking in a foreign language can make many people, particularly those from a strong uncertainty avoidance society, highly uncomfortable, as there is far less likelihood of being able to attain the accuracy which is so highly valued in a culture such as Japan which has the largest disparity with a Western country such as USA in terms of ambiguity tolerance (Hofstede ,1991, p113).

\subsection{Imagined Identities and Communities}

As for the third research question, the responses to survey questions and the content analysis and thematic analysis of the students' comments show that the concepts of imagined identities such as social, professional, global, bicultural or multicultural identities are in operation in L2 motivation. However, based on the comments, most of the students expressed clearly that they have no desire to join English communities and live abroad permanently and there is not a desire to identify with and adopt the target culture. The desire to make foreign friends and being in international scenes is mostly aimed at instrumental goals of English learning rather than adopting a new cultural identity and being part of the target language community. Based on table 2, only two students expressed an explicit tendency to join English-speaking communities. Rest of the participants either asserted clearly that they don't have a desire to join English communities and live abroad permanently or they just didn't respond to the question. Some examples of comments are as the following:

\section{Excerpt 4:}

"My goal is to go to many countries which I hope to go by using own English, but I think I would not live in foreign countries because I like the Japanese life."

"My goal of learning English is the level that I can live in foreign countries. I don't hope to join some English speaking communities."

"to work at United Nations. I'm not eager to join English speaking communities, but if I should, the ability of English is indeed needed."

"My goal is that I understand every lyric in English at once. I'd like to join English speaking communities like U.K or U.S.A for a business."

"My goal of learning English is to active use English in whatever field. I hope I can join English communities that can discuss the issue with famous experts."

As it can be observed from these comments, for these students, the concept of imagined community is operational in their learning goals. As Norton (2002) said, despite the fact that students have many incentives to learn language, their membership in an imagined community is probably one of the most important reasons behind their language investment. The desire to be a member of imagined communities even in the imaginary levels can facilitate the learning and speaking practices.

However, here joining the English communities is not for integrative goals rather, it is for career or instrumental orientations. This lack of integrative motivation or resistance to identify with the target culture can be due to cultural and social context. Several aspects of Japanese culture such as ethnocentrism and collectivism might result in resistance to adopting new cultural identities, which can be one of the major motivational forces in English learning for EFL learners of other countries. Nonetheless, the imagined community can be also referred to any communities that a learner desires to join where s/he imagines to practice the language. As a student mentioned her desire to use English to join and communicate with the community of experts is a motivation for her learning. The research results also show identity creations and changes in some students after English learning. One student mentioned "English is special to me because it is the one which created my identity." Nevertheless, some learners clearly said that they felt no 
changes in their identities.

Another theme emerged in the comments was expansion of the horizons and thoughts by learning the new language. As seen in the following excerpt, in the first students' comment, the traces of identity changes felt by the learner can be observed while the second student feels no changes despite the broadening of his thoughts and perspective horizons.

Excerpt 5:

"I think I changed. I got to open mind. After change, I'm same when I speak both language."

"I think my thought became wider. Also, I've got some confidence in myself, and I can express myself better. I don't feel different when I speak English, but due to my English skill, I have to say many things in very simple way. So the other people would think I'm different."

Excerpt 6:

"When I was in the UK, I think I could say my opinions more strongly than in Japan. I think it is not because of the English language, but the UK culture. But, after coming back to Japan, I turned to be a typical Japanese, I think. Even though I speak English in Japan, I don't feel my different personality."

"After having had the education in U.S., my way of thinking was totally different from the one of Japanese. Both when speaking in Japanese and in English that never changed for several years even after I came back to Japan. However, slightly my way of thinking began to be effected by the way of Japanese, and right now even when I speak English my thinking is of Japanese, that is what I feel."

For this student, the Identity change depends on the context of practice. This shows well the cultural restrictions of identity development and the dynamism and context-dependency of identity. Different communication norms seem to hinder the possibility for free expression of thoughts and adopting new identities for this learner. A similar view was observed in another student:

Excerpt 7:

"After having had the education in U.S., my way of thinking was totally different from the one of Japanese. Both when speaking in Japanese and in English that never changed for several years even after I came back to Japan. However, slightly my way of thinking began to be effected by the way of Japanese, and right now even when I speak English my thinking is of Japanese, that is what I feel."

This shows how study abroad and speaking English affected the identity of this learner. The new identity persisted for several years before it was affected by the cultural context of his native language. Finally the new identity diminished even while speaking in the target language. This also indicates an identity conflict between English speaker and Japanese speaker identities which can be rooted in linguistic, communicative and socio-cultural differences between Japanese and English. The impact of culture on students' language practices and identity development is well understood by looking at Kunihiro's (1975) words about Japanese communication styles.

"In Japan, language, communication through language, has not received the same emphasis as in the West... It has been considered poor policy to use words as a tool to express one's views, to persuade the other fellow or to establish any depth of understanding. Language as an instrument of debate or arguments is considered even more disagreeable and is accordingly avoided. Thus, in Japanese society, use of words becomes a sort of ritual, not often to be taken at face value. It is only one possible means of communication, not the means of communication as is often the case among English speakers" (p.97).

It can be concluded that these contextual differences which result in identity conflicts might be the major reason for Japanese EFL learners and identity is an important factor in learning a foreign language like English.

\subsection{Motivational Self-System}

L2 self includes the ideal L2 self, indicating the representation of the attributes that someone would ideally like to possess (i.e. a representation of personal hopes aspirations or wishes), and ought-to L2 self, referring to the attributes that one believes one ought to possess (i.e. a representation of someone else's sense of duty, obligations or responsibilities). Most of the learning goals are mentioned as what the learners aspire or hope to be in the future. In other words, the learners' learning goals are in line with their ideal selves. For example, for this student, being an active converser who can organize and express his opinion freely is associated with his ideal self:

Excerpt 8: 
"When I speak Japanese, I think very seriously and fall silent, so I often lose my chance to express my opinion in the conversation. But if I can speak English fluently, I will become more active, and organize my opinion in the conversation."

"I will have to succeed my mother's factory, so I don't need English skill for living foreign country. But I think I should learn it to get broad information and to prepare to do business with foreign companies."

"To work at United Nations. I'm not eager to join English speaking communities, but if I should, the ability of English is indeed needed."

For two of the learners, the ought-to self is well into practice as language learning is associated with their future occupational duties. Rest of the participants however, associated their learning goals with their ideal selves, which shows the high motivation of learners.

Another component of motivational self-system is learning experience which plays a significant role in students' motivation. In response to the question about positive and negative experiences of language learning, the following comments were received:

Excerpt 9:

"I am taking a project-based course in English in Denmark. Half of students are from Denmark and others are from European countries and USA. All of them speak English very well. I'm only Asian and speak English worth. We always discuss projects and ideas. They have a lot of ideas and opinions, so they talk a lot. However only people who argue opinions proceed group work. Additionally, if they don't understand what I said (maybe because of my poor English), most of them often ignore and start talking their thoughts. It was hard for me to get used to."

"When I met with my teacher for the first time since few years who do really good for me and I respect him, He sweat a lot And said "Sorry I am stinky." And I said "Ah, Yes" I said that without understanding "stinky" My teacher's face has been bad mood a little then. I could not understand what happen at that time, But I got to know few days later. I regret this thing so much. If the teacher just does not contact so long to me, I feel that he hates me."

"I have an experience to for a homestay, and so I like English."

"When I travel overseas, it's essential to communicate to others in English. If someone can understand what I'm saying, I feel excited. That kind of experience encourages me to keep studying. If not, it makes me think back on what was wrong and think about what I should do next time. Either way, I take it positively."

These comments clarify the anxiety and negative feelings the learners go through while having intercultural experiences with foreigners or native speakers, which can be demotivating due to differences in communication styles and intercultural relationships. For some learners it can hinder their learning and motivation while for others it can be educational. However, positive experiences like positive encounters with foreigners can reinforce motivation.

\section{Discussion}

Overall, the results indicate that the EFL learners participated in this study possessed a high level of motivation, international posture and positive attitude toward the target language and culture. Moreover, in accordance with what scholars found, Integrativeness appeared to be an inadequate measure of motivation for EFL learners like Japanese who have little access or desire to join English communities and identify with them (Graddol, 2006). Furthermore, L2 learners have aspirations towards desired social or professional identities (Kanno \& Norton, 2003) and English language learning is aimed toward fulfilling their ideal selves and imagined identities. As this study suggested, the participants accommodated the idea of being proficient in the target language in their ideal and ought-to self which might be the reason why they were highly motivated towards the target language (Dörnyei \& Ushioda, 2009).

For some learners, English learning has created a new identity or broadened their minds while for most of them learning English is not associated with fundamental identity changes. There are several inhibitory factors operating against identity changes and English language practices including anxiety and low linguistic self-confidence. The identity conflicts and resistance can be related to cultural and communicative differences between Japanese and English as well. This identity conflict can result in resistance to practice speaking English in various EFL contexts. 
Moreover, the Japanese L2 learners participated in this research have little desire to join English language communities and identify with the target culture. This lack of desire together with language learning anxiety could be interpreted with a reference to cultural factors as well. Some cultural aspects of Japanese such as collectivism, uncertainty avoidance, ethnocentrism or resistance to new cultural identities inherent in Japanese culture (Yashima, $2000 \&$ Hashimoto, 2013) might be major factors which influence students' motivation, linguistic self-confidence and adopting new language identities. Also as Norton (2000) claims, these learners might have less access to learning opportunities to construct cultural concepts and L2 identity, which facilitate their foreign language acquisition process.

Another point which is noteworthy is that the type of motivations can affect learner' learning in a way that once the learners have higher integrative orientations, defined by Gardner \& Lambert (1972) as "reflecting a sincere and personal interest in the people and culture represented by the other group..." (p.132), they are investing into the language more in comparison with the participants having instrumental orientations. For Japanese students, instrumental orientation seems to be stronger than the integrative one which can be interpreted as one factor behind learning difficulties since Instrumental motivation might not lead to full investment in English language learning. In short, this study tries to clarify the need for understanding how the identities of EFL learners are shaped and affected by the cultural and educational aspects of the learning environment. While the number of participants is not enough to make generalizations to all Japanese EFL learners, this research provides an understanding of EFL learners' language learning motivations and renders a deeper representation of their identities and self-concepts.

\section{Conclusion}

It is inevitable that the more a learner invests in a foreign language, the more opportunities s/he will have to acquire the targeted language and be involved with the targeted culture. Hence, if the concept of learning a second language is a part of learner identity, students will be more motivated to learn it. A higher motivation will make students invest more into learning the language, and more investment is quite likely to bring higher levels of success. Therefore, in addition to teaching grammatical facts and developing language skills, language teachers should also try very hard to make sure that their students will be fully aware of why they are learning a foreign language and what advantages they may gain if they happen to acquire one.

Japanese learners might be less motivated or invested in language skills that are not directly related to their ideal or out-to selves. In order to motivate the students, it will be helpful to inform them of the identity repertoires and introduce the idea of ideal self to help them clarify their goals of language learning and connect them to their ideal self. Engaging students' transportable identities (e.g. as football fan, amateur photographer, film buff) can stimulate a much higher level of personal involvement, effort and investment from students than traditional teacher-student talk, where students are invariably positioned as language learners who are merely practicing or demonstrating knowledge of the language rather than expressing their own voices and identities through the language. Morgan (1997) asserted that the way teachers position learners within the classroom and their "conceptual predispositions" in relation to the theories and methods of teaching can "define and constrain the emancipatory potential of identity work" in a language learning classroom (p. 447). In other words, we need to engage their own identities and interests in our lessons and promote a sense of continuity between what they learn and do in the classroom, and who they are and what they are interested in doing in their lives outside the classroom, now and in the future. In this manner, as Little (2004, p. 106) puts it, 'what they learn becomes part of what they are'.

\section{References}

Boxer, D., \& Cortes-Conde, F. (2000). Identity and ideology: Culture and pragmatics in content- based ESL. In J. K. Hall, \& L. S. Verplaestse (Eds.), Second and foreign language learning through classroom interaction (pp. 203-219). Mahwah: Lawrence Erlbaum Associates.

Dörnyei, Z. (2005). The psychology of the language learner: Individual differences in second language acquisition. Mahwah, NJ: Lawrence Erlbaum.

Dörnyei, Z., \& Ushioda, E. (2009). Motivation, language identities and the L2 self: A theoretical overview. In Z. Dörnyei \& E. Ushioda (Eds.), Motivation, language identity and the L2 self (pp. 1-8). Bristol: Multilingual Matters.

ETS. (2010). Test and Score Data Summary for TOEFL Internet-based and Paper-based Tests. Princeton: Education 
Testing Service.

Gao, X., \& Lamb, T. (2011). Exploring links between identity, motivation and autonomy. In G. Murray, X. Gao, \& T. Lamb (Eds.), Identity, motivation and autonomy in language learning (pp. 1-8). Bristol: Multilingual Matters.

Gardner, R. C. (1985). Social psychology and second language learning: The role of attitudes and motivation. London: Edward Arnold.

Gardner, R. C. (2011). The socio-educational model of second language acquisition. Canadian Issues, 24-27.

Gardner, R. C., \& Lambert, W. E. (1959). Motivational variables in second-language acquisition. Canadian Journal of Psychology, 13, 266-272.

Gardner, R. C., \& Lambert, W. E. (1972). Attitudes and motivation in second language learning. Rowley, MA: Newbury House.

Gee, J., \& Crawford, V. (1998). Two kinds of teenagers: Language, identity and social class. In Alvermann, D., Moore, D., \& Waff, D. (Eds.), Reconceptualizing the literacies in adolescents' lives. Mahwah: NJ: Erlbaum.

Hashimoto, K. (2013). The Japanization of English Language Education: Promotion of the national language within foreign language policy. In James W. Tollefson (Ed.), Language Policies in Education ( $2^{\text {nd }}$ ed.). (pp. 175-190) New York United States: Routledge.

Ha, P. L. (2008). Teaching English as an international language: Identity, resistance, negotiation. Clevedon: England Multilingual Matters.

Hashimoto, K., (2013). The Japanization of English Language Education: Promotion of the national language within foreign language policy. In James W. Tollefson (Ed.), Language Policies in Education (2 ${ }^{\text {nd }}$ ed.). (pp. 175-190) New York United States: Routledge.

Hofstede, G. (1991). Cultures and organizations. Berkshire: McGraw-Hill Book Company Europe.

Kanno, Y. (2003). Imagined communities, school visions, and the education of bilingual students in Japan. Journal of Language, Identity \& Education, 2(4), 285-300. https://doi.org/10.1207/S15327701JLIE0204_4

Kanno, Y., \& Norton, B. (2003). Imagined communities and educational possibilities: Introduction. Journal of Language, Identity \& Education, 2(4), 241-249. https://doi.org/10.1207/S15327701JLIE0204_1

Kunihoro, M. (1973). Indigenous barriers to communication. Japan Interpreter, 8(1), 96-108.

Lantolf, J.P., \& Pavlenko, A. (2001). Second language activity theory: Understanding second language learners as people. In M.P. Breen (Ed.), Learner contributions to language learning (pp. 141-158). Harlow, England: Longman.

Lamb, M. (2004). Integrative motivation in a globalizing world. System, 32(1), 3-19. https://doi.org/10.1016/j.system.2003.04.002

Lamb, M. (2009). Situating the L2 self: Two Indonesian school learners of English. In Z. Dörnyei \& E. Ushioda (Eds.), Motivation, language identity and the L2 self (pp. 229-247). Bristol: Multilingual Matters.

Luke, A. (1996). Text and Discourse in Education: An Introduction to Critical Discourse Analysis. Retrieved from http://www.jstor.org/p. 1 - 48.

Matsuda, A. (2000). Japanese attitudes toward English: A case study of high school students. Unpublished doctoral dissertation, Purdue University, West Lafayette, Indiana.

McKay, S. L., \& Wong, S-L. C. (1996). Multiple discourses, multiple identities: Investment and agency in second-language learning among Chinese adolescent immigrant students. Harvard Educational Review, 66, 577-608. https://doi.org/10.17763/haer.66.3.n47r06u264944865

Miller, J. (2009). Teacher professional role identity. In A. Burns, \& J.C. Richards (Eds.), The Cambridge guide to second language teacher education (pp. 172-181). New York: Cambridge University Press.

Morgan, B. (1997). Identity and intonation: Linking dynamic processes in an ESL classroom. TESOL Quarterly, 31, 431-450. https://doi.org/10.2307/3587833

Norton, B. (1995). Social identity, investment, and language learning. TESOL Quarterly, 29, 9-31. https://doi.org/10.2307/3587803

Norton, B. (2000). Identity and language learning: Gender, ethnicity and educational change. Harlow, England: 
Longman/Pearson Education Limited.

Norton, B. (2001). Non-participation, imagined communities and the language classroom. In M. P. Breen (Ed.), Learner contributions to language learning (pp. 159-171). New York, NY: Pearson Education.

Norton, B. (2013). Identity and language learning: Extending the conversation. Bristol: Multilingual Matters.

Ohata, K. (2005). Potential sources of anxiety for Japanese learners of English: Preliminary case of interviews with five Japanese college students in the US. TESL-EJ, 9(3), 2-23.

Pavlenko, A. (2002). Poststructuralist approaches to the study of social factors in L2. In V. Cook (ed.), Portraits of the L2 user. Clevedon, Multilingual Matters, pp. 277-302.

Richards, K. (2006). 'Being the teacher': identity and classroom conversation. Applied Linguistics, 27(1), 51-77. https://doi.org/10.1093/applin/ami041

Tsui, A. (1995). Introducing classroom interaction. London: Penguin.

Van Lier, L. (2007). Action-based teaching, autonomy and identity. Innovation in Language Learning and Teaching, 1(1), 46-65. https://doi.org/10.2167/illt42.0

Wang, C.-L. (2010). Toward a second language socialization perspective: Issues in study abroad research. Foreign Language Annals, 43(1), 50-63. https://doi.org/10.1111/j.1944-9720.2010.01059.x

Yashima, T. (2000). Orientations and motivation in foreign language learning: A study of Japanese college students. JACET Bulletin, 31, 121-133. 